\title{
RUINS OF THE ROGOWIEC CASTLE WITH NATURA 2000 HABITATS AS A REFUGIUM FOR TERRESTRIAL GASTROPODS IN THE SUCHE MOUNTAINS (CENTRAL SUDETES, SW POLAND)
}

\author{
TOMASZ K. MALTZ1*, MAŁGORZATA PROĆKÓWㄹ, ELŻBIETA KuŹNIK-KOWALSKA², \\ JAROSEAW PROĆKÓW ${ }^{3}$
}

\begin{abstract}
${ }^{1}$ Museum of Natural History, University of Wrocław, Sienkiewicza 21, 50-335 Wrocław, Poland (e-mail: tomasz.maltz@uwr.edu.pl, malgorzata.prockow@uwr.edu.pl); TKM (ㅇ) https://orcid.org/0000-0002-4105-9848, MP i https://orcid.org/0000-0003-2240-7306 ${ }^{2}$ Department of Invertebrate Systematics and Ecology, Institute of Biology, Wrocław University of Environmental and Life Sciences, Kożuchowska 5b, 51-631 Wrocław, Poland (e-mail: elzbieta.kowalska@upwr.edu.pl); (1) https://orcid.org/0000-0002-5509-0336 ${ }^{3}$ Department of Plant Biology, Institute of Biology, Wrocław University of Environmental and Life Sciences, Kożuchowska 5b, 51-631 Wrocław, Poland (e-mail: jaroslaw.prockow@upwr.edu.pl); (1) https://orcid.org/0000-0003-4100-3438

*corresponding author
\end{abstract}

ABSTRACT: The castle ruins are situated on the summit of Rogowiec - a high, rocky hill in the Suche Mts. The castle and its hill hold a rich malacofauna. The presence of numerous forest species inhabiting leaf-litter is a unique feature of this malacocoenosis. Its composition seems to be directly associated with sycamore maple and beech forests with a tall lush ground cover, overgrowing the slopes around the castle. This habitat offers very good conditions for terrestrial gastropods. The fauna of Rogowiec includes species which are rare and/or endangered in the Sudetes, such as Orcula doliolum (Bruguière), Tandonia rustica (Millet), Semilimax semilimax (J. Férussac), Clausilia parvula Férussac, Helicigona lapicida (Linnaeus) and Causa holosericum (Studer). The Rogowiec castle ruins, like many other castle remnants, constitute a refugium for terrestrial faunas. This and the priority habitats of Natura 2000 (Tilio-Acerion forest of slopes, screes and ravines as well as Galio odorati-Fagenion beech forest) determine the environmental value of the castle hill, which fully entitles the site to be classified as a legally protected reserve.

KEY WORDS: terrestrial malacofauna, Natura 2000 forest communities, castle ruins, refugium, Sudetes, Poland

\section{INTRODUCTION}

The Sudetes are among the better investigated regions of Poland considering the species composition and distribution of molluscan fauna. Detailed studies have been carried out in the Sudetes including the Karkonosze Mts (WIKTOR \& WIKTOR 1968), Kaczawskie Mts with their foothills (WIKTOR 1964a, POKRYSZKO 1984), Kłodzko Basin (WIKTOR 1964b), Wałbrzych Basin with Wałbrzych Highlands (WIKTOR 1959, MALTZ 1999). The Suche Mts constitute the easternmost range of the Kamienne Mts, one of the mesoregions of the Central Sudetes (KONDRACKI 2002). Their geological structure is dominated by Permian volcanic rocks: melaphyres and red porphyres with thickness exceeding 1,500 m (OBERC 1972). Such formations do not usually contain calcium carbonate thus the malacofauna of the mountains is relatively poor and not very diverse. Moreover, water poverty is characteristic of the mountains and 
forest communities consist here in more than $90 \%$ of the spruce forests and Luzulo nemorosae-Fagetum (= Luzulo luzuloidis-Fagetum) beech forests with poorly developed undergrowth (KUCZYŃSKA \& MACICKA 1984). These are also negative factors which limit the occurrence of molluscs. In such habitats remains of ancient abandoned buildings and walls, built of stones and bricks cemented with mortar containing a considerable amount of calcium, provide particularly favourable conditions for calciphilous plant and animal species. Calcium carbonate, the component of mortar, undergoes chemical reactions with water (hydrolysis) or water and carbon dioxide (chemical dissolution). This increases the content of calcium cations in the substratum. The importance of castle ruins as natural refugia for land snail communities have been pointed on several occasions (e.g. ALEXANDROWICZ 1995, 2013, JUŘIČKOVÁ \& KUČERA 2005a, b). The Rogowiec castle ruins are situated on Mount Rogowiec - one of summits in the Suche Mts. The area may be regarded as a refugium. The aim of this paper was a detailed faunistic analysis of the gastropod species richness of the ruins and the slopes of the castle hill, and its comparison with malacocoenoses from the neighbouring mountain areas.

\section{STUDY AREA}

The castle ruins are located near the Grzmiąca village, in the northern part of the Suche Mountains (Central Sudetes, SW Poland, Fig. 1). The castle is situated on a high, rocky hill Rogowiec (870 m a.s.l., $\left.50^{\circ} 41^{\prime} 36.5^{\prime \prime} \mathrm{N}, 16^{\circ} 18^{\prime} 54.1^{\prime \prime} \mathrm{E}\right)$. It is the highest located castle in Poland. The hill is built of Permian melaphyres and its slopes are steep and cut by small and deep valleys. The castle was built in the 13th century and consisted of the upper castle, inter-walls, the lower castle and a courtyard inside the castle. In the 15th century it was blown up and has remained a ruin since then. Fragments of the outer walls, remains of the towers and a fragment of a cylindrical tower with ca. $3 \mathrm{~m}$ high have been preserved now (http://cit.walbrzych.pl/info/352/) (Fig. 2).

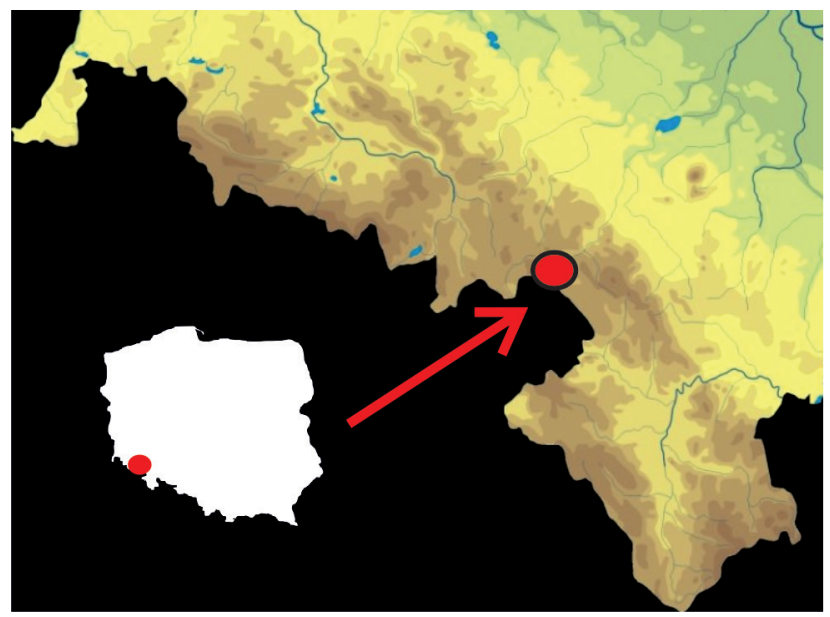

Fig. 1. Location of the Rogowiec castle ruins (Suche Mts, Central Sudetes, SW Poland)

\section{MATERIAL AND METHODS}

The location was visited twice, on the 26th of September 2010 and on the 12th of July 2011, and samples were taken from two habitats: the castle ruins and the slopes of the castle hill, in the direct vicinity of the castle. Gastropods were collected by eye and litter samples, of $10 \mathrm{l}$ volume each, were taken and sieved through a sieve of $10 \times 10 \mathrm{~mm}$ mesh. The samples were dried and passed through a sieve with a small mesh $(2 \times 2 \mathrm{~mm})$. Live individuals of Helicidae and slugs were identified in the field and released, the remaining material was identified in the laboratory and deposited in the collection of the Museum of Natural History, University of Wrocław. The nomenclature and systematic arrangement follow WiKTOR (2004).

The division into ecological groups was based on RIEDEL's (1988) classification. In order to compare gastropod communities from the studied locality and from the other areas (data from: WIKTOR 1964b,
POKRYSZKO 1984, MALTZ 1999, MALTZ et al. 2018) the following indices were used: 1) index of faunistic originality (IFO) (EJSMONT-KARABIN 1995), 2) valorisation index $\left(\mathrm{RED}=\mathrm{S} \mathrm{Th}_{\mathrm{i}}\right.$, where $\mathrm{Th}-$ coefficient of danger to the species; for NT Th $=2$, for VU Th $=3), 3)$ index of biocoenosis value $(\mathrm{REB}=\mathrm{S}$ $\mathrm{Th}_{\mathrm{i}} / \mathrm{n}$, where $\mathrm{n}$ - number of all species), 4) index of "special care" species $(\mathrm{RES}=\mathrm{s} / \mathrm{n} \times 100 \%, \mathrm{~s}-$ the number of legally protected species in this paper) (CZACHOROWSKI et al. 2004) and 5) Nei index (N) (CAMERON \& POKRYSZKO 2005). Classification of endangered species for calculating the indices RED, REB and RES was adopted after WIKTOR \& RIEDEL (2002).

For precise descriptions of the vegetation overgrowing the castle ruins and their slopes the detailed botanical field survey was conducted. Plant nomenclature follows THE PLANT LIST (2013) and plant communities are after OBERDORFER (1994). 


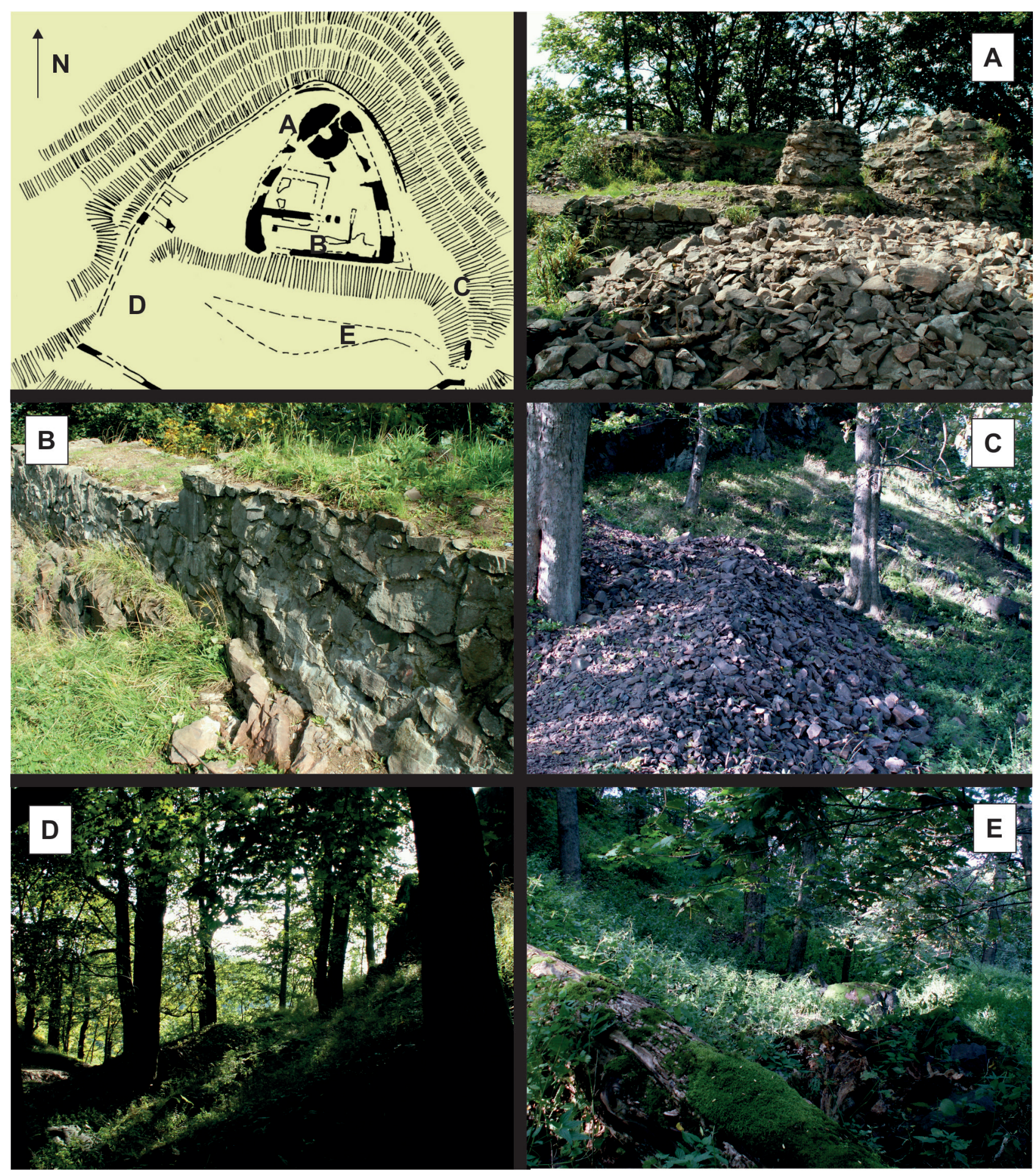

Fig. 2. Map of the Rogowiec castle ruins with particular habitat types: A - remains of castle tower, B - remains of walls, C - south-eastern slope, D - south-western slope, E - southern slope (plan: http://www.zamki.pl/?idzamku=rogowiec; photos: T. K. MALTZ)

\section{RESULTS}

\section{MOLLUSCAN FAUNA}

A total of 42 gastropod species were collected in the castle ruins (25 species) and the slopes of castle hill (39 species). Ecological groups were distinguished considering: habitat preferences, humidity, microhabitat preferences as well as designating calciphilous and synanthropic species (Table 1). 
According to habitat preferences forest snails were dominant components of the studied fauna, constituting nearly $55 \%$ of the malacocoenosis (Fig. 4 ). They were represented by 23 species and together with shrub-dwellers (7 species) formed the majority (71\%). Euryoecious species (8 species) and snails preferring open habitats (4 species) jointly represented slightly over $28 \%$ of the malacocoenosis. The malacofauna of Rogowiec was dominated by mesophilous taxa (ca. 81\%). Calciphilous and

Table 1. List of species recorded in the Rogowiec castle ruins: CR - castle ruins; SL - slope of castle hill; hab. - habitat preferences: $\mathrm{F}$ - forest, $\mathrm{S}$ - shrubs, $\mathrm{O}$ - open habitats, $\mathrm{E}$ - euryoecious species; hum. - humidity: $\mathrm{H}$ - hygrophilous, $\mathrm{M}$ - mesophilous; micr. - microhabitat preferences: L - leaf-litter, $\mathrm{W}$ - wood, $\mathrm{R}$ - rocks; Ca - calciphilous species, syn. - synanthropic species

\begin{tabular}{|c|c|c|c|c|c|c|c|c|}
\hline \multirow{2}{*}{ No. } & \multirow{2}{*}{ Species } & \multirow{2}{*}{ CR } & \multirow{2}{*}{ SL } & \multicolumn{5}{|c|}{ Ecological groups } \\
\hline & & & & hab. & hum. & micr. & $\mathrm{Ca}$ & syn. \\
\hline 1. & Carychium minimum & & + & $E$ & $\mathrm{H}$ & $\mathrm{L}$ & & \\
\hline 2. & Carychium tridentatum & & + & $\mathrm{E}$ & $\mathrm{H}$ & $\mathrm{L}$ & & \\
\hline 3. & Cochlicopa lubrica & & + & $\mathrm{E}$ & M & & & \\
\hline 4. & Orcula doliolum & + & + & $\mathrm{O}$ & M & $\mathrm{R}$ & + & \\
\hline 5. & Vallonia pulchella & + & & $\mathrm{O}$ & M & & & \\
\hline 6. & Vallonia excentrica & + & & $\mathrm{O}$ & M & & & \\
\hline 7. & Acanthinula aculeata & & + & $\mathrm{F}$ & $\mathrm{H}$ & $\mathrm{L}$ & & \\
\hline 8. & Ena montana & + & + & $\mathrm{F}$ & M & & & \\
\hline 9. & Ena obscura & & + & $\mathrm{F}$ & M & W & & \\
\hline 10. & Discus rotundatus & + & + & $S$ & M & & & \\
\hline 11. & Arion rufus & + & + & $\mathrm{E}$ & M & & & + \\
\hline 12. & Arion fuscus & + & + & $\mathrm{E}$ & M & & & \\
\hline 13. & Arion distinctus & + & + & $S$ & M & & & + \\
\hline 14. & Arion silvaticus & & + & $\mathrm{F}$ & M & $\mathrm{L}$ & & \\
\hline 15. & Vitrina pellucida & + & + & $\mathrm{E}$ & M & & & \\
\hline 16. & Semilimax semilimax & + & + & $\mathrm{F}$ & $\mathrm{H}$ & $\mathrm{L}$ & & \\
\hline 17. & Vitrea diaphana & + & + & $\mathrm{F}$ & $\mathrm{H}$ & $\mathrm{L}$ & & \\
\hline 18. & Vitrea subrimata & & + & $\mathrm{F}$ & $\mathrm{H}$ & $\mathrm{L}$ & & \\
\hline 19. & Aegopinella pura & + & + & $\mathrm{F}$ & M & $\mathrm{L}$ & & \\
\hline 20. & Aegopinella epipedostoma & + & + & $\mathrm{F}$ & M & $\mathrm{L}$ & & \\
\hline 21. & Aegopinella minor & & + & $\mathrm{E}$ & M & $\mathrm{L}$ & + & \\
\hline 22. & Oxychilus cellarius & + & + & $S$ & M & & & \\
\hline 23. & Tandonia rustica & + & + & $\mathrm{F}$ & M & $\mathrm{R}$ & + & \\
\hline 24. & Limax cinereoniger & & + & $\mathrm{F}$ & M & W & & \\
\hline 25. & Malacolimax tenellus & + & + & $\mathrm{F}$ & M & & & \\
\hline 26. & Lehmannia marginata & + & + & $\mathrm{F}$ & M & W & & \\
\hline 27. & Deroceras agreste & + & + & $\mathrm{O}$ & M & & & \\
\hline 28. & Boettgerilla pallens & & + & $\mathrm{E}$ & M & $\mathrm{L}$ & & + \\
\hline 29. & Cochlodina laminata & & + & $\mathrm{F}$ & M & W & & \\
\hline 30. & Ruthenica filograna & & + & $\mathrm{F}$ & M & $\mathrm{L}$ & & \\
\hline 31. & Macrogastra plicatula & + & + & $\mathrm{F}$ & M & & & \\
\hline 32. & Macrogastra ventricosa & & + & $\mathrm{F}$ & $\mathrm{H}$ & W & & \\
\hline 33. & Clausilia parvula & + & & $S$ & M & $\mathrm{R}$ & + & \\
\hline 34. & Clausilia pumila & & + & $\mathrm{F}$ & M & W & & \\
\hline 35. & Alinda biplicata & + & + & $S$ & M & & & \\
\hline 36. & Perforatella incarnata & + & + & $\mathrm{F}$ & M & & & \\
\hline 37. & Arianta arbustorum & + & + & $\mathrm{F}$ & M & & & \\
\hline 38. & Helicigona lapicida & + & + & $\mathrm{F}$ & M & W & & \\
\hline 39. & Isognomostoma isognomostoma & & + & $\mathrm{F}$ & $\mathrm{H}$ & & & \\
\hline 40. & Causa holosericum & & + & $\mathrm{F}$ & M & $\mathrm{R}$ & & \\
\hline 41. & Cepaea hortensis & & + & $S$ & M & & & \\
\hline 42. & Helix pomatia & + & + & $S$ & M & & & \\
\hline$\Sigma$ & 42 & 25 & 39 & & & & & \\
\hline
\end{tabular}




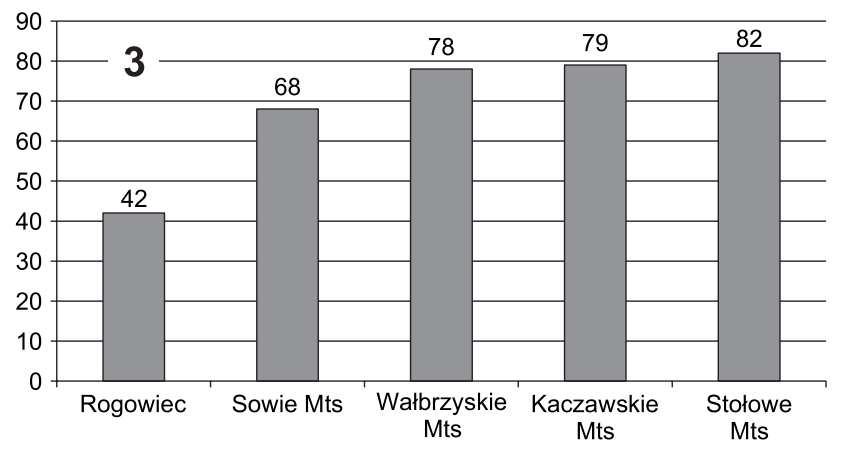

Number of species

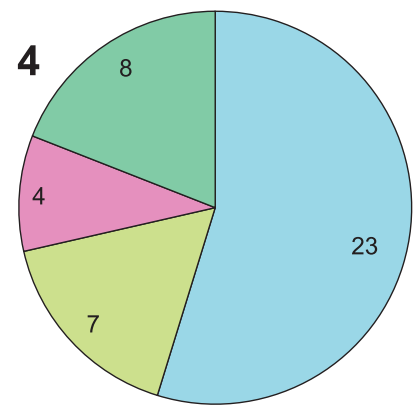

$\square \mathrm{F} \square \mathrm{S} \square \mathrm{O} \square \mathrm{E}$

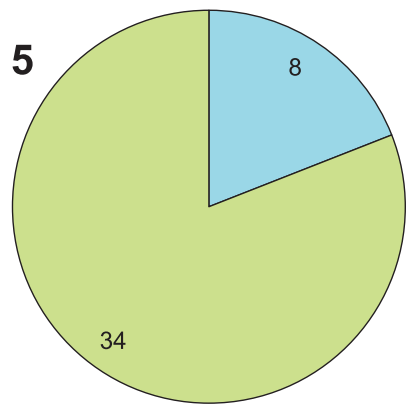

$\square \mathrm{H} \square \mathrm{M}$

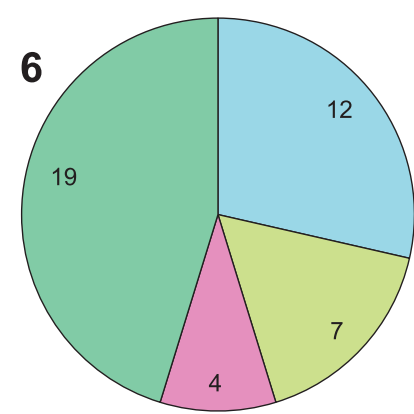

$\square$ L $\square$ W $\square$ R $\square$ other

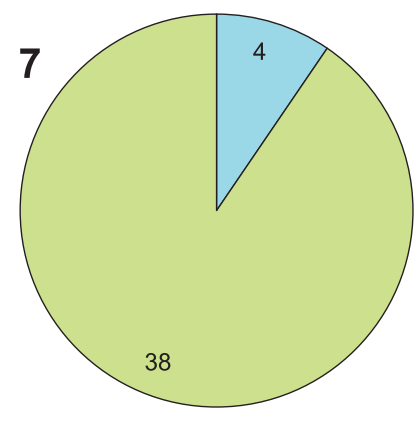

$\square$ Ca $\square$ other

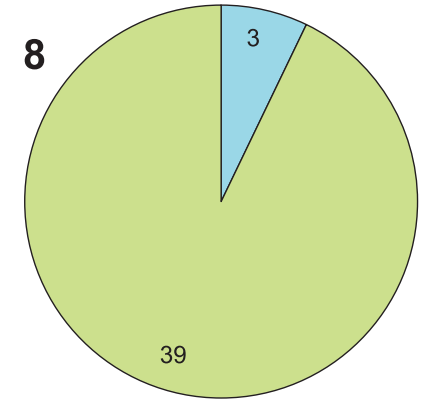

$\square$ syn. $\square$ other

Figs 3-8. Comparison of the number of species among Rogowiec and four Sudetic mountain ranges (3), and ecological composition of the Rogowiec castle malacocoenosis (4 - habitat preferences; 5 - humidity; 6 - microhabitat preferences; 7 - calciphiles; 8 - synanthropes)

Abbreviations: $\mathrm{F}$ - forest, $\mathrm{S}$ - shrubs, $\mathrm{O}$ - open habitats, $\mathrm{E}$ - euryoecious species; $\mathrm{H}$ - hygrophilous species, $\mathrm{M}$ - mesophilous species; L - leaf-litter, W - wood, R - rocks; Ca - calciphilous species, syn. - synanthropic species

synanthropic species constituted, $9.5 \%$ and $7 \%$ of all recorded species, respectively (Figs $5-8$ ).

The studied malacofauna includes seven red-listed species among which $O$. doliolum has VU category and six remaining NT category: S. semilimax, T. rustica, C. parvula, H. lapicida, C. holosericum and H. pomatia

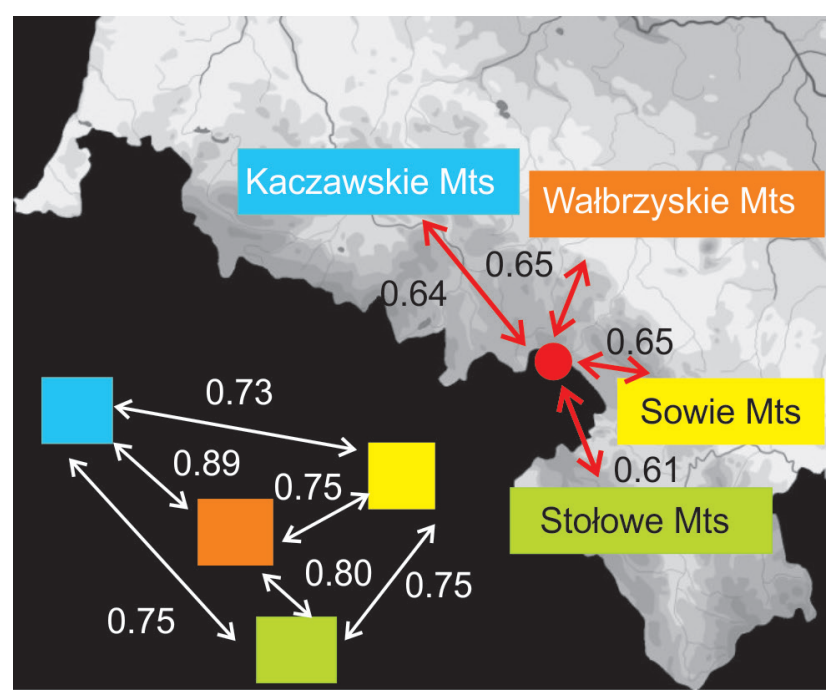

Fig. 9. Faunal similarity between the Rogowiec castle ruins (red point) and surrounding mountain areas (Nei index)
(WIKTOR \& RIEDEL 2002). Three of them, i.e. T. rustica, $H$. lapicida and $H$. pomatia, are partly protected by the Polish law (DZ. U. 2016). The indices of faunistic value for the studied locality are: $\mathrm{RED}=15, \mathrm{REB}=$ 0.36 and RES $=7 \%(n=42)$. The value of the index of faunistic originality (IFO) is 0.622 .

The similarities ( $\mathrm{N}$ - Nei indices) among Rogowiec and the malacocoenoses of the Kaczawskie Mts, Wałbrzyskie Mts, Sowie Mts and Stołowe Mts are shown in Fig. 9.

\section{BOTANICAL SURVEY}

The detailed botanical field inventory of the vegetation overgrowing the castle and its slopes revealed that the hill around the ruins was mainly covered by sycamore maple and beech forests. This Tilio-Acerion forest of slopes, screes and ravines is a Natura 2000 habitat $\left({ }^{*} 9180\right)$, which has the priority feature within the European Union because of the scarcity of this habitat type. In the tree layer the dominant species is Acer pseudoplatanus L. with Larix decidua Mill. in some places. In the shrub layer there are A. pseudoplatanus and Corylus avellana L. Where the slope was $50-60^{\circ}$, there was no possibility to assess the forest undergrowth. In particular, in the south the Tilio-Acerion 
forest was identified, with the following trees (tree layer density $=90 \%)$ : A. pseudoplatanus (dominant), Fraxinus excelsior L. and Ulmus glabra Huds. The latter species also grows in the shrub layer, which is only $5 \%$ of the density. In the undergrowth (herb layer cover $=90 \%$ ) Poa nemoralis L. dominates, with an admixture of the typical species such as: Elymus caninus (L.) L., Senecio ovatus Willd., Campanula trachelium L., Festuca gigantea (L.) Vill., Aconitum variegatum L. (fully protected by law, Dz. U. 2014), Dactylis glomerata L. (as D. polygama Horv.), Fraxinus excelsior, Mycelis muralis (L.) Dumort., Silene dioica (L.) Clairv., Prenanthes purpurea L.

North of the castle, Tilio-Acerion forest was also present, however, with certain differences. The tree layer (density $=50 \%$ ) was dominated by $A$. pseudoplatanus with less abundant U. glabra. Both species also grew in the shrub layer but the elm was sporadic. The layer density was up to $50 \%$. The undergrowth (herb layer cover $=80-90 \%$ ) was characterised by a high frequency of synanthropic species: Urtica dioica L. and Alliaria petiolata (M. Bieb.) Cavara \& Grande. Additionally, 18 more species were recorded here, among which of special interest are Aconitum variegatum L., Galium odoratum (L.) Scop. (both partly protected by the Polish law, DZ. U. 2014), Ranunculus platanifolius L., Prenanthes purpurea L.

Below the castle, along the yellow hiking trail, there is a Galio odorati-Fagenion beech forest (Natura 2000 habitat (9130)), with dominant F. sylvatica L. and A. pseudoplatanus, as an admixture (tree layer density $=80 \%$ ). Beech is a component of both the shrub and herb layers (for both $5 \%$ of density or cover). In the undergrowth (herb layer cover = 90\%) species typical of this community, such as: $G$. odoratum, Paris quadrifolia L., Hordelymus europaeus (L.) Jess. ex Harz, S. ovatus were recorded.

The inner walls of the Rogowiec castle are mostly north- and only partly east-facing. They are covered by a mosaic of different plant communities of unknown syntaxonomic identity, for example a community with Poa pratensis L. with the following accompanying species: Galium mollugo L., Silene dioica, Arenaria serpyllifolia L., and with a rich moss cover. In many places rock ferns were found, for example Cystopteris fragilis (L.) Bernh. and Dryopteris filix-mas (L.) Schott. Above them there are loose thickets of Rubus caesius $\mathrm{L}$. with a young brushwood of $A$. pseudoplatanus as well as $C$. trachelium and $U$. dioica.

On rocks at the bottom of the inner part of the castle plant communities of an unknown syntaxonomic position were observed, dominated by $D$. glomerata and admixture of E. caninus, Linaria vulgaris Mill., Impatiens noli-tangere L., Arrhenatherum elatius (L.) P. Beauv. ex J. Presl \& C. Presl., Clinopodium nepeta subsp. glandulosum (Req.) Govaerts, Scrophularia nodosa L., and Campanula trachelium.

Around the castle grass communities were found, including A. elatius, D. glomerata, E. caninus, Poa pratensis, Aconitum variegatum, Lathyrus pratensis L., Linaria vulgaris and Arenaria serpyllifolia.

In the forest surrounding the castle, the following species, fully or partly protected by the Polish law (DZ. U. 2014) were recorded: Lilium martagon L., A. variegatum (mostly in the sycamore forest and also within the grass communities) and G. odoratum. Species usually more common in the mountains included: R. platanifolius, Sambucus racemosa L., Veronica montana L., S. dioica, Senecio ovatus, Prenanthes purpurea.

beech forests with a tall lush ground cover, growing on the slopes around the castle, constitute very good habitats from the malacological point of view. Gastropods of these habitats are represented by species associated with forest or shrub habitats on the one hand and by hygrophiles on the other (Figs 4-5). Among the Polish Carpathian castles a comparatively similar number of species was recorded only in Muszyna (41 species) and Rytno (36 species), both surrounded by a mixed forest also providing microhabitats which are particularly favourable for molluscs (ALEXANDROWICZ 1995). All the remaining 28 castles hold between 10 and 26 species of terrestrial gastropods (ALEXANDROWICZ 1995), whereas molluscan communities, studied at 123 castles in the Czech Republic, were richer in species in only one case, i.e. the Blansek castle (46 species). In the remaining castles $12-39$ species were recorded (JUǨiČKOVÁ 2005). 
The exceptional feature of the Rogowiec malacofauna is the occurrence of species which are not often found in the Sudetes or in Poland and are red-listed (WIKTOR \& RIEDEL 2002). O. doliolum is one of the noteworthy species in this group. It prefers warm habitats with high calcium content; it can also be found in forests in leaf-litter and rock rubble, or on dry walls (WELTER-SCHULTES 2012). In the studied area, $O$. doliolum occurs in both the castle ruins and in the talus slope forest on the castle hill (Table 1, Fig. 2). Its isolated localities are scattered in southern Poland. In the Sudetes it is known from the Kaczawskie Mts: Mt. Ostrzyca, Mt. Miłek, Mt. Połom and the Wleń castle (POKRYSZKO 1984). The species was also found in the Trosky castle near Jičín and the Rychleby castle near Javornik - the nearest localities in the Czech Republic (JUŘIČKOVÁ 2005, JUŘIČKOVÁ et al. 2005). Generally it forms isolated and insular populations which can be regarded as occupying local refugia (ALEXANDROWICZ \& ALEXANDROWICZ 2017). Other valuable species recorded in Rogowiec were: T. rustica, S. semilimax, C. parvula, H. lapicida and C. holosericum. In Poland T. rustica is regarded as a thermophilous relict from the Atlantic Period, found only in the foothills of the Western Sudetes (POKRYSZKO \& MALTZ 2007). Rogowiec is thus the easternmost locality of this species in Poland and the northernmost site in Europe. The limestone talus slopes offer favourable conditions for T. rustica. Two species from Rogowiec, i.e. C. parvula and H. lapicida, belong to the group of "castle species", which are more frequent or abundant in castles than in natural habitats (JUŘIČKOVÁ \& KUČERA 2005b). They are rock-dwellers. C. parvula mostly inhabits leaf-litter and rock rubble, sometimes climbing rocks (MALTZ 1999), while $H$. lapicida lives under bark of deciduous tree trunks, on rock faces and in rock crevices (POKRYSZKO \& MALTZ 2007). Other species which are faunistically important in the malacofauna of Rogowiec include $S$. semilimax, mainly occurring in forests and humid microhabitats and C. holosericum - an Alpine species and a forest-dweller preferring rocky substratum, which lives on the forest floor (POKRYSZKO \& MALTZ 2007). The preserved fragment of the forest, probably from the mediaeval period, may have allowed survival of such species as T. rustica and H. lapicida, which may have had a wider, continuous distribution range in the past. We assume that $O$. doliolum and C. parvula may have been introduced with rock material used to build the castle.

The castle hill in Rogowiec is inhabited by a fauna whose composition and structure do not differ greatly from those of the malacocoenoses of the neighbouring mountain ranges, i.e. the Kaczawskie Mts, Wałbrzyskie Mts, Sowie Mts and Stołowe Mts. This is shown by the values of Nei index (Fig. 9).

Our results suggest that the environmental conditions of castle ruins present an unusual ecological phenomenon. They are complex man-made habitats which are often very different from those of the surrounding landscape. Therefore, castle ruins represent islands of very high habitat diversity which considerably increase the species richness of the landscape (JUŘiČKOVÁ \& KUČERA 2005b).

The castle hill in Rogowiec, together with the castle ruins, should be placed under legal habitat protection (e.g. as nature reserve). The malacofauna of Rogowiec is exceptional in the Suche Mts, due to both the occurrence of Natura 2000 habitat types suitable for land snails (Tilio-Acerion forest and Galio odorati-Fagenion beech forest) and the castle phenomenon. This is also supported by the presence of other protected animals (DZ. U. 2016) such as the fire salamander Salamandra salamandra (Linnaeus, 1758), the common toad Bufo bufo (Linnaeus, 1758), the common lizard Zootoca vivipara (Lichtenstein, 1823), the slowworm Anguis fragilis Linnaeus, 1758 (authors' personal observations).

\section{REFERENCES}

AlEXANDROWICZ S. W. 1995. Ruins of Carpathian castles as refuges of land snails. Ochrona Przyrody 52: 3-18.

AlEXANDROWICZ W. P. 2013. The malacofauna of the castle ruins in Melsztyn near Tarnów (Rożnów Foothills, Southern Poland). Folia Malacologica 21: 9-18. https:// doi.org/10.12657/folmal.021.002

AleXandrowicz W. P., AleXandrowicz S. W. 2017. Malakofauna wzgórza zamkowego Lipowiec - rezerwatu przyrody w Babicach. [Mollusc fauna of the Castle Hill Lipowiec - nature reserve In Babice (S Poland)]. Chrońmy Przyrodę Ojczystą 73: 3-16.

CAmeron R. A. D., PokryszKo B. M. 2005. Estimating the species richness and composition of land mollusc communities: problems, consequences and practical advice. Journal of Conchology 38: 529-547.

CZACHOROWSKI S., PAKULNICKA J., SZCZEPAŃSKI W. 2004. Waloryzacja obszarów przyrodniczo cennych - w poszukiwaniu nowego wskaźnika. Trichopteron 11: 11-12.

Dz. U. 2014. Rozporządzenie Ministra Środowiska z dnia 9 października 2014 r. w sprawie ochrony gatunkowej roślin. Dz.U. 2014, poz. 1409.

Dz. U. 2016. Rozporządzenie Ministra Środowiska z dnia 16 grudnia 2016 r. w sprawie ochrony gatunkowej zwierząt. Dz.U. 2016, poz. 2183.

EJSMONT-KARABIN J. 1995. Rotifer occurrence in relation to age, depth and trophic state of quarry lakes. 
Hydrobiologia 131: 21-28. https://doi.org/10.1007/ BF00025927

JuŘIČKOVÁ L. 2005. Měkkýši (Mollusca) hradů jako ekologického fenoménu (Česká republika) [Molluscs (Mollusca) of castles as an ecological phenomenon (Czech Republic)]. Malacologica Bohemoslovaca 3: 100-148. http://mollusca.sav.sk/pdf/3/3.Jurickova.pdf

JUŘiČKOVÁ L., BERAN L., DVOŘÁK L., HLAVÁČ J. Č., HORSÁK M., Hrabáková M., Maltz T. K., POKRYSZKo B. M. 2005. Mollusc fauna of the Rychlebské hory (Czech Republic). Folia Malacologica 13: 9-23. https://doi. org/10.12657/folmal.013.002

JUŘIČKOVÁ L., KUČERA T. 2005a. Ruins of medieval castles as refuges for endangered species of molluscs. Journal of Molluscan Studies 71: 233-246. https://doi. org/10.1093/mollus/eyi031

JUŘIČKOVÁ L., KUČERA T. 2005b. Ruins of medieval castles as refuges of interesting land snails in the landscape. Contributions to Soil Zoology in Central Europe. In: TAJOVSKÝ K., SCHLAGHAMERSKÝ J., PIXL V. (eds). ISB ASCR, České Budějovice, pp. 41-46.

KONDRACKI J. 2002. Geografia regionalna Polski. PWN, Warszawa.

KUCZYŃSKA I., MACICKA T. 1984. Zbiorowiska leśne wschodniej części Gór Kamiennych. Acta Universitatis Wratislaviensis. Prace Botaniczne 27: 79-119.

Maltz T. K. 1999. Ślimaki (Gastropoda) Kotliny i Pogórza Wałbrzyskiego. Folia Malacologica 7: 51-72. https:// doi.org/10.12657/folmal.007.006

MALTZ T. K., POKRYSZKO B. M., WIKTOR A. 2018. Ślimaki i małże (Gastropoda et Bivalvia) Gór Stołowych. In: KABAŁA C., KADEJ M., KĄCKI Z., MAZUR T., MiśCICKI S. (eds). Góry Stołowe - przyroda i ludzie. Park Narodowy Gór Stołowych, Kudowa Zdrój, pp. 143-154.

OBERC J. 1972. Budowa geologiczna Polski. T. IV Tektonika, cz. 2, Sudety i obszary przyległe. Wydawnictwo Geologiczne, Warszawa.

OBERDORFER E. 1994. Pflanzensoziologische Exkursionsflora. 7 Auflage. Verlag Eugen Ulmer, Stuttgart.

POKRYSZKO B. M. 1984. Ślimaki Gór i Pogórza Kaczawskiego (Sudety Zachodnie). Acta Universitatis Wratislaviensis. Prace Zoologiczne 16: 21-52.
POKRYSZKO B. M., MALTZ T. K. 2007. Rare and endangered terrestrial gastropods of Lower Silesia (SW. Poland) current status and perspectives. Acta Universitatis Latviensis 723: 7-20.

RIEDEL A. 1988. Ślimaki lądowe (Gastropoda terrestria). Katalog Fauny Polski 36. PWN, Warszawa.

SPRICK J. 1921. Schneckenfunde in Schlesien. Archiv für Molluskenkunde 53: 252-256.

THE PlANT LisT 2013. The Plant List version 1.1. Available online at http://www.theplantlist.org/ (accessed 1 January 2018).

WELTER-SCHUltes F. W. 2012. European non-marine molluscs, a guide for species identification. Planet Poster Editions, Göttingen.

WIKTOR A. 1959. Mięczaki strefy przełomów pod Książem koło Wałbrzycha. Prace Komisji Biologicznej Poznańskiego Towarzystwa Przyjaciół Nauk 19: 329363.

WIKTOR A. 1964a. Interesująca fauna mięczaków na górze „Miłek” w Górach Kaczawskich. Chrońmy Przyrodę Ojczystą 20: 20-26.

WiKTOR A. 1964b. Mięczaki Ziemi Kłodzkiej i gór przyległych. Studium faunistyczno-zoogeograficzne. Prace Komisji Biologicznej Poznańskiego Towarzystwa Przyjaciół Nauk 29: 1-132.

WIKTOR A. 2004. Ślimaki lądowe Polski. Mantis, Olsztyn.

WikTor A., Riedel A. 2002. Ślimaki lądowe Gastropoda Terrestria. In: GŁOWACIŃSKI Z. (ed.). Czerwona lista zwierząt ginących i zagrożonych w Polsce. Institute of Nature Conservation of the Polish Academy of Sciences, Kraków, pp. 29-33.

WikTOR J., WiKTOR A. 1968. Charakterystyka fauny mięczaków polskiej części Karkonoszy ze szczególnym uwzględnieniem Karkonoskiego Parku Narodowego. Ochrona Przyrody 33: 193-214.

Received: November 27th, 2018

Revised: February 12th, 2019

Accepted: February 14th, 2019 Published on-line: March 19th, 2019 